\title{
Diversity of protein-crop management in western France
}

\author{
Matthieu Carof ${ }^{1}$ (D) $\cdot$ Olivier Godinot $^{1} \cdot$ Aude Ridier $^{2}$ \\ Accepted: 22 January 2019 / Published online: 27 February 2019 \\ (C) INRA and Springer-Verlag France SAS, part of Springer Nature 2019
}

\begin{abstract}
In the European Union (EU), local production of protein crops (faba bean, field pea, lupins) is of primary interest to help farmers depend less on purchased feed, provide agronomic benefits to cropping systems, and increase the EU's protein self-sufficiency. Nonetheless, farmers rarely grow protein crops, which currently represent less than $1 \%$ of the EU's arable land. We assumed that exploration of farmers' practices will bring focus on (i) their motivations for growing protein crops, so that extension programs can be improved based on these motivations, and (ii) the diversity of their crop management so that promising ones can be disseminated. In western France, a two-step survey was conducted among farmers who grew protein crops. The first step was an online survey of 127 farmers that aimed to characterize their farming systems. The second step was a face-to-face survey (69 volunteers from the 127 farmers) that aimed to collect precise data on management of protein crops. The main motivations of surveyed farmers for growing protein crops were related to (i) replacing imported soybean with farm-grown protein crops and (ii) pre-crop values of protein crops (i.e., benefits of protein crops for subsequent crops). Based on conventional farmers' answers, we estimated a pre-crop value of $118 € \mathrm{ha}^{-1}$, which notably contributes to gross profit at the crop-rotation scale. Moreover, in our study, yields of protein crops did not differ significantly between conventional and organic systems. This offers an interesting opportunity for conventional systems to integrate organic practices, such as complex intercropping, to reduce variable costs (costs of seeds, pesticides, regulators, and chemical fertilizers) and increase gross profits. This study shows for the first time that, in western France, pre-crop values of protein crops and their suitability for low-input systems are undervalued and could be emphasized more strongly to encourage their adoption.
\end{abstract}

Keywords Protein crops $\cdot$ Faba bean $\cdot$ Field pea $\cdot$ Lupins $\cdot$ Crop management systems $\cdot$ Innovation $\cdot$ Farm survey

\section{Introduction}

Grain legumes are crops from the Fabaceae family grown for their dry seeds, which are used for feed or food. In the European Union (EU), the term "protein crops" includes only some of the grain legumes: faba bean (Vicia faba L.), field pea (Pisum sativum L.), and lupins (Lupinus angustifolius L., Lupinus albus L., Lupinus luteus L.). The percentage of the EU's arable land used for protein crops has decreased in the past several decades, from $1.3 \%$ in 1961 to $0.8 \%$ in 2014 (FAO 2018). Protein crop production has also declined in

Matthieu Carof

matthieu.carof@agrocampus-ouest.fr

1 SAS, AGROCAMPUS OUEST, 65 rue de Saint-Brieuc, CS 84215, F-35042 Rennes cedex, France

2 SMART-LERECO, AGROCAMPUS OUEST, 65 rue de Saint-Brieuc, CS 84215, F-35042 Rennes cedex, France
France, where, since 2000, its percentage has not exceeded $2.6 \%$. From 1961 to 2014, human consumption of protein crops decreased dramatically, but as livestock consumption increased greatly, total consumption of protein crops has grown (Bues et al. 2013). As a consequence, today's protein-crop production in the EU does not cover its needs for protein-rich feeds: almost $70 \%$ of domestic consumption is imported, mainly as soybean and soybean meal from Brazil, Argentina, and the USA (Watson et al. 2017). The situation is slightly better in France, where less than $40 \%$ of protein-rich feeds are imported. However, the main sources of protein-rich feeds produced in France are sunflower and rapeseed oil byproducts (Peyronnet et al. 2014).

This decline is partly explained by EU policies since the 1960s. In the framework of General Agreement on Tariffs and Trade negotiations, the EU implemented price support for its cereals and in return allowed unlimited imports of soybean, soybean meal, and other oilseeds from the USA for zero or almost zero duty (Mahé and Laroche-Dupraz 2000). Subsequent Common Agricultural Policy reforms made the 
EU's protein-crop production much less economically attractive than cereal production (Häusling 2011). Since the 2000s, cereal prices, even though more variable, have largely increased, which further reduced the competitiveness of protein and oilseed crops compared to cereals. Overall, EU policies led to a decrease in protein crop area and thus to lessdiversified cropping systems. Only recently has the EU adopted policies to re-encourage domestic production of protein crops (Häusling 2011).

Several authors have reviewed benefits of protein crops, grown as sole crops or as intercrops (e.g., Angus et al. 2015; Bedoussac et al. 2015; Preissel et al. 2015; Watson et al. 2017). Protein crops can fix atmospheric nitrogen symbiotically, which supplies nitrogen not only to themselves, but also to following crops (in a crop rotation) and to component crops (in intercropping) (Fig. 1). At both temporal (crop rotation) and spatial (intercropping) scales, protein crops may reduce weed pressure, favor populations of beneficial insects for crop defense, and improve soil structure. In cereal-dominated crop rotations, protein crops break pest and disease cycles, reducing pesticide requirements for following crops. In cereal/ protein-crop intercropping systems, the protein content of cereal grains is higher than that when the same cereals are grown as sole crops. At the food-system level, protein crops also provide high-quality protein for humans, and phytochemicals present in the seeds of some protein crops may be of particular interest for them.

At present, these benefits are not clearly valued by EU farmers, who see protein crops as less profitable than other grain crops, especially wheat (von Richthofen et al. 2006). Likewise, even at the cropping-system scale, protein-crop systems often remain less profitable than specialized cereal-crop systems (e.g., Reckling et al. 2016; Ridier et al. 2016). Furthermore, protein crops have significantly lower interannual yield stability than non-protein crops, especially in Europe (Cernay et al.
2015), due to sensitivity to water stress, weak ability to compete with weeds, sensitivity to pathogens, and harvest difficulties (e.g., lodging, late maturity) (Voisin et al. 2014; Watson et al. 2017). Finally, replacing soybean meal with protein crops in animal feed may decrease growth performance, especially of pigs and poultry (Watson et al. 2017).

Expanding production of grain legumes also faces difficulties due to technological lock-in of production systems, resulting from co-evolution of interrelated organizations, technologies, knowledge, values, and environments, which discourages actors from adopting alternative technologies, even if they are more beneficial (Magrini et al. 2016). For example, a recent study of farmers in Luxembourg identified that a major obstacle to growing grain legumes is a lack of knowledge about them and of extension services for them (Zimmer et al. 2016).

To identify benefits and drawbacks of protein crops, most studies perform field experiments, rarely farm surveys. The latter may be more useful, however, to ask farmers about their motivations for growing protein crops, because their perceptions may differ from results of field experiments. Indeed, some of the benefits identified in experiments may not be sufficiently profitable to justify introducing protein crops to a commercial farm, and experiments cannot identify most socio-technical barriers.

In this study, we surveyed a sample of farmers growing protein crops in western France about (i) their motivations for growing them, so that extension programs can be improved based on their perceptions, and (ii) crop management systems they commonly use for them, so that the most promising ones can be developed for farmers. We assumed that exploration and analysis of farmers' perceptions would supplement studies based on historical and statistical data. We also assumed that exploration and analysis of farmers' practices would bring focus on innovative types of crop management that could help overcome the weak development of current production systems.

Fig. 1 Protein crops such as faba bean (Vicia faba L.) are of particular interest for farmers since they can convert nitrogen gas into ammonia within root nodules that contain symbiotic bacteria. This biological nitrogen fixation may allow farmers to reduce the use of nitrogen fertilizers. Despite this benefit (among others), however, production of protein crops in Europe remains low. (Photographs: M. Carof)

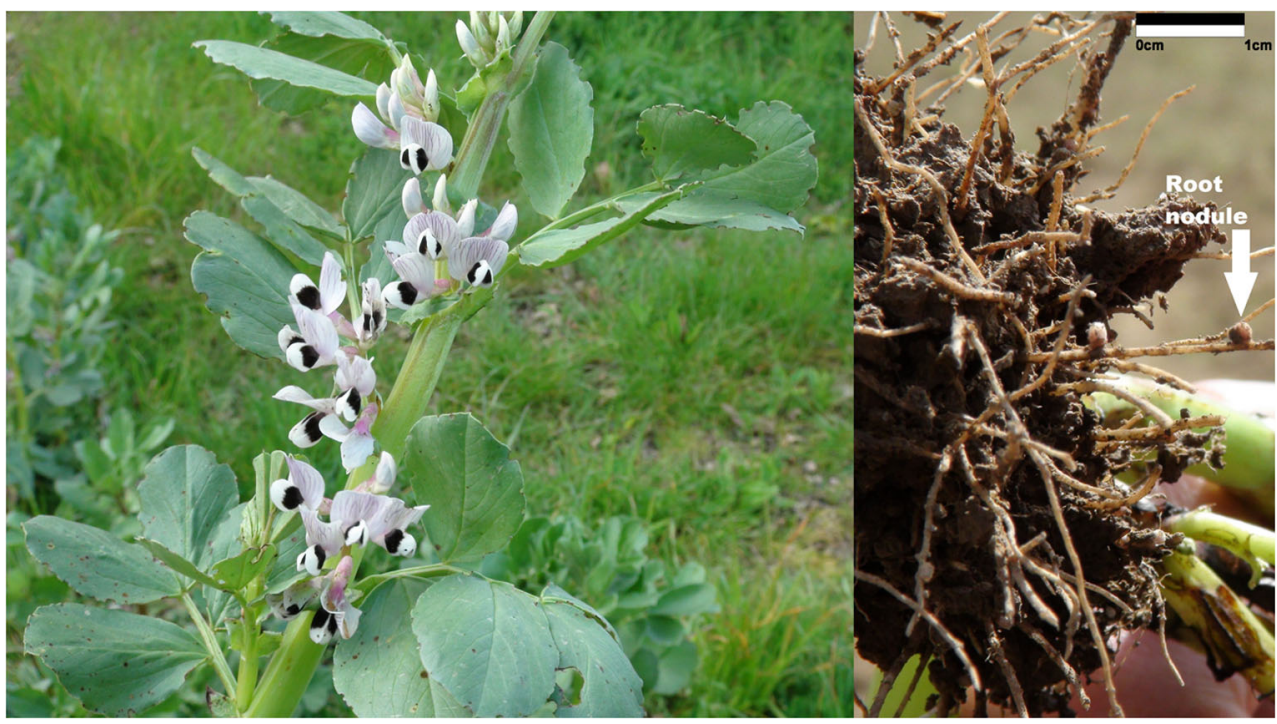




\section{Materials and methods}

\subsection{The survey}

A two-step survey was conducted among farmers who grew protein crops in Brittany and Pays de la Loire, western France. This survey was part of a research and development project called SECURIPROT-PROGRAILIVE (Pôle Agronomique Ouest 2016).

The first step was an online survey during spring-summer 2014. Farmers were contacted using the regional agricultural press and partners of the SECURIPROT-PROGRAILIVE project; 165 farmers completed the online survey. The aims of the online survey were to (i) briefly characterize farming systems of protein-crop producers and (ii) ask producers to participate in a face-to-face survey. The online survey covered the following points:

- Description of the farming system: legal status of the farm, number of workers, arable land area, inventory of main types of production (used to define farm type), yields of main crops, sizes, and production of livestock activities (if any).

- Focus on protein crops: number of years of experience growing them, areas, average yields, reasons to grow and stop growing them, main problems encountered.

The online survey contained two types of questions: numerical input (e.g., arable land area, protein-crop area) and multiple choice (e.g., inventory of main types of production, reasons for growing protein crops).

The second step was a face-to-face survey of 69 volunteers from the 165 farmers, conducted during winter 2014-2015, which aimed to identify variability in protein-crop management among farms. Data were collected on productivity and crop management practices of the most commonly grown protein crop on each of the surveyed farms. Also, farmers' appraisals of effects on following crops were collected (in particular of nitrogen application rate as well as number and application rate of pesticides). Each face-to-face survey lasted approximately $2 \mathrm{~h}$.

\subsection{Data analysis}

In the online survey, 127 of the 165 farmers declared that they still produced protein crops; thus, we analyzed only 127 farms. We purposely focused only on farmers who produced protein crops, since our objective was to improve knowledge about current management of, and innovative practices for, protein crops. In the face-to-face survey, we analyzed the 69 farms.

\subsubsection{Descriptors and performance indicators}

To describe and assess performances of protein-crop management, indicators were calculated per hectare using detailed crop management practices. The indicators concerned three dimensions: (i) environmental-treatment frequency index, (ii) productive - dry grain yield and working time, and (iii) economic-gross product and gross profit. Treatment frequency index was calculated as the number of approved doses applied to a crop (from soil management before sowing to harvest, excluding seed treatment). Dry grain yield (hereafter "yield") was calculated by multiplying harvested grain yield by dry matter content; when not available, a standard dry matter content of $86 \%$ was used. Gross product was calculated by multiplying yield by the 2007-2014 median price of each crop obtained from FranceAgriMer and CRITER ${ }^{\circledR}$ software (Craheix 2015; FranceAgriMer 2016). For organic crops for which median prices were not available, we used the 2014 price of each crop obtained from local agricultural organizations (IBB 2015; Chambre régionale d'agriculture des Pays de la Loire 2017). Finally, gross product of intercrops was calculated based on the proportion (by mass) of each species' yield at harvest; for the 12 farmers who did not provide this information, we used the proportion (by mass) of seeds of each intercropped species at sowing, although it is well known that the ratio of intercrops at harvest can differ greatly from that at sowing. Gross profit equaled gross product minus variable costs, which included seeds, pesticides, regulators, and chemical fertilizers. Costs of inputs were calculated by multiplying application rates by the price of each product applied, obtained from CRITER ${ }^{\circledR}$ software. To standardize the comparison, we assumed that all farmers bought seeds, even though some used seeds that they had saved from their own farms. Working time was estimated from the practices declared by farmers and the mean amount of time $\left(\mathrm{min} \mathrm{ha}{ }^{-1}\right)$ required for each practice obtained from CRITER ${ }^{\circledR}$ software.

Three qualitative indicators were also estimated, using multiple-choice questions. First, farmers were asked to what degree growing a protein crop as a preceding crop changed the amounts or types of nitrogen fertilizer or pesticides that they applied to the following crop (e.g., no change, up to $10 \mathrm{~kg} \mathrm{~N}^{-1}$ less, up to $20 \mathrm{~kg} \mathrm{~N} \mathrm{ha}^{-1}$ less). Second, they were asked to estimate the increase in yield of the crop following a protein crop (e.g., no increase, up to $0.5 \mathrm{t} \mathrm{ha}^{-1}$ more, up to $1.0 \mathrm{t} \mathrm{ha}^{-1}$ more). Third, they were asked if they spent less, as much, or more time to grow protein crops than to grow wheat.

\subsubsection{Statistical analysis}

Descriptive statistics (percentage distributions, means, standard deviations) and inferential statistics were 
calculated using R software (R Core Team 2016). To determine if two population means were equal, we first tested normal distribution of the two populations using the Shapiro-Wilk normality test. If they were normally distributed, the two means were compared using Student's $t$ test (if population variances were equal, based on an $F$ test of the equality of two variances) or Welch's $t$ test (if variances were unequal). If the two populations were not normally distributed, their medians were compared using the Wilcoxon-Mann-Whitney's test.

\section{Results and discussion}

\subsection{Descriptive statistics of the samples}

\subsubsection{Characteristics of the sampled farms}

Most farms in the online sample (108 of the 127 farms) were livestock farms (Table 1a). Among livestock farms, more than half were bovine dairy farms. Also, 55 of the 127 farms were organic (or converting to it). The

Table 1 Descriptive statistics of sampled farms growing protein crops (faba bean, field pea, lupins) in western France (Brittany, Pays de la Loire)

(a) Categorical variables: number of individuals $(n)$ and percentage

Variable
Farm type
Specialist field crops and/or vegetables
Specialist ruminant livestock
Specialist pig and/or poultry
Mixed livestock holdings
Mixed crop livestock
Farms producing under an official quality scheme
Respect for the environment: organic farming ${ }^{b}$
Guarantee of superior quality: "Label Rouge"
Guarantee of origin: PDO/PGI
Unspecified
Farms producing protein crops
Sole crop only
Intercrop only
Sole crop and intercrop
Unspecified

$\begin{array}{ll}\text { Online survey } & \\ n & \text { Percentage }(\%)^{\mathrm{a}} \\ 127 & - \\ 19 & 15 \\ 47 & 37 \\ 10 & 8 \\ 13 & 10 \\ 38 & 30 \\ 61 & 48 \\ 55 & 43 \\ 5 & 4 \\ 3 & 2 \\ 1 & 1 \\ 127 & 100 \\ 61 & 48 \\ 47 & 37 \\ 16 & 13 \\ 3 & 2\end{array}$

$\begin{array}{ll}\text { Face-to-face survey } \\ n & \text { Percentage }(\%)^{\mathrm{a}} \\ 69 & - \\ 10 & 14 \\ 22 & 32 \\ 5 & 7 \\ 11 & 16 \\ 21 & 30 \\ 34 & 49 \\ 31 & 45 \\ 3 & 4 \\ 0 & 0 \\ 1 & 1 \\ 69 & 100 \\ 33 & 48 \\ 26 & 38 \\ 9 & 13 \\ 1 & 1\end{array}$

(b) Continuous variables: number of answers $(n), 95 \%$ confidence intervals of absolute and relative means

\begin{tabular}{|c|c|c|c|c|c|c|}
\hline \multirow[t]{2}{*}{ Variable } & \multicolumn{3}{|c|}{ Online survey } & \multicolumn{3}{|c|}{ Face-to-face survey } \\
\hline & $n$ & Absolute & Relative $(\%)^{\mathrm{c}}$ & $n$ & Absolute & Relative $(\%)^{\mathrm{c}}$ \\
\hline Farm arable land (ha) & 127 & $110 \pm 11$ & - & 69 & $119 \pm 15$ & - \\
\hline Protein crop area (ha) & 123 & $11 \pm 2$ & $12 \pm 2$ & 67 & $13 \pm 3$ & $12 \pm 3$ \\
\hline Sole crop & 74 & $9 \pm 2$ & $8 \pm 2$ & 39 & $10 \pm 3$ & $8 \pm 3$ \\
\hline Faba bean & 42 & $7 \pm 2$ & $6 \pm 1$ & 25 & $8 \pm 2$ & $6 \pm 2$ \\
\hline Field pea & 34 & $9 \pm 2$ & $7 \pm 2$ & 14 & $10 \pm 4$ & $8 \pm 5$ \\
\hline Lupins & 16 & $4 \pm 2$ & $4 \pm 2$ & 12 & $4 \pm 2$ & $3 \pm 2$ \\
\hline Intercrop $^{\mathrm{d}}$ & 62 & $12 \pm 3$ & $15 \pm 4$ & 34 & $14 \pm 4$ & $15 \pm 5$ \\
\hline Faba bean & 42 & $10 \pm 3$ & $12 \pm 3$ & 24 & $11 \pm 5$ & $12 \pm 4$ \\
\hline Field pea & 45 & $9 \pm 2$ & $12 \pm 4$ & 25 & $10 \pm 3$ & $10 \pm 3$ \\
\hline Lupins & 10 & $4 \pm 2$ & $4 \pm 2$ & 6 & $4 \pm 2$ & $2 \pm 2$ \\
\hline
\end{tabular}

$P D O$ protected designation of origin, $P G I$ protected geographical indication

${ }^{\text {a }}$ Percentages are calculated relative to the entire dataset

${ }^{\mathrm{b}}$ Farms in conversion to organic farming were also included (three in the online survey, zero in the face-to-face survey)

${ }^{\mathrm{c}}$ Relative values are calculated as percentages of farms' arable land area

${ }^{\mathrm{d}}$ Farmers specified the area of each crop (faba bean, field pea, lupins; spring-sown, autumn-sown; sole crop, intercrop). When several protein crops were intercropped, the area was counted only once 
percentages of livestock farms and organic farms were the same in the online and face-to-face surveys.

The high percentage of livestock farms in the sample is not surprising, since Brittany and Pays de la Loire are the two most important administrative regions for dairy and pig production in France (Eurostat 2015). Moreover, it is consistent with the fact that protein crops are used mainly as ingredients in animal feed (e.g., for on-farm feed production). At national level, however, the area in protein crops is larger in regions specialized in field-crop production than in regions specialized in livestock production (SSP 2016).

In the sample, $43 \%$ of farms were organic, far more than the $5.4 \%$ of French farms that were organic in early 2014 (SSP 2016); this result emphasizes that protein crops are essential to organic farming because they supply (i) nitrogen to the soil in the place of chemical nitrogen fertilizers and (ii) farm-grown feed at reasonable costs (Zander et al. 2016).

\subsubsection{Protein crops on the sampled farms}

Faba bean and field pea were the most common protein crops produced on sampled farms (Table 1b). Despite their benefits (e.g., high protein content and quality, high phosphorus use efficiency), lupins were the least common protein crop in our sample, which is consistent with the study of Murphy-Bokern et al. (2014) based on FAOSTAT data (1961-2011). Lucas et al. (2015) suggest that this is particularly due to insufficient breeding efforts to develop more productive varieties.

Nearly half of farmers produced protein crops only as sole crops, and just over one third produced them only as intercrops: few farmers produced protein crops as both sole crops and intercrops (Table 1a). Cropping strategy (sole cropping, intercropping) was strongly related to the farming system, since $89 \%$ of organic farmers produced protein crops as intercrops, whereas only $19 \%$ of conventional farmers did so.

\subsection{Surveyed farmers' motivations for protein crops}

Regardless of species, the main reasons for surveyed farmers to grow protein crops were related to replacing imported soybean with locally produced protein crops and the positive effects of protein crops as preceding crops (Fig. 2), both well-known benefits of protein crops (Voisin et al. 2014).

We proposed several mechanisms that might encourage farmers to increase protein crop area on their farms. The main mechanisms selected were economic: increasing public subsidies for protein crops ( $31 \%$ of surveyed farmers), increasing gross profit of protein crops (27\%), and increasing the price of imported soybean (20\%). Conventional farmers endorsed these mechanisms much more than organic farmers and selected other mechanisms, such as increasing technical knowledge and plant breeding (24\%) and increasing involvement of agricultural cooperatives $(22 \%)$.

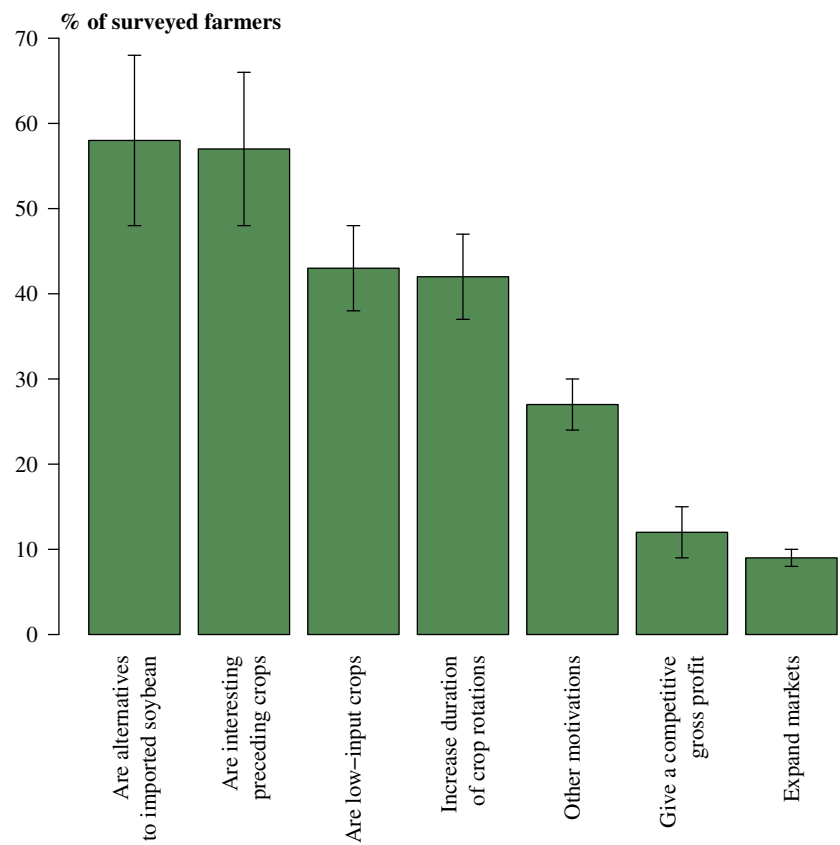

Fig. 2 Reasons why 127 surveyed farmers decided to grow protein crops. Reasons were proposed to farmers, and multiple answers were possible. Bars represent means of answers for the three crops (faba bean, field pea, and lupins), weighted by the frequency of each crop. Error bars represent standard deviations of the weighted means

Some mechanisms depended on farm type. Approximately $26 \%$ of specialized pig and/or poultry farmers highlighted that lifting the ban on manure spreading on protein crops would be important for increasing protein crop area on their farms (this ban exists in French nitrate vulnerable zones). Better technical knowledge of crop management, plant breeding efforts, and economic incentives were highlighted by specialized fieldcrop and vegetable farmers. In agreement with these elements, Meynard et al. (2018) identified that the small number of crop varieties, lack of crop-protection solutions, and lack of technical references for minor crops were obstacles to crop diversification (including protein crops). They added that actions to diversify crops should include, simultaneously and in a coordinated manner, commercial markets, stakeholder coordination, and improvement in varieties and management practices. Magrini et al. (2016) came to similar conclusions.

\subsection{Diversity of performances of protein crops on the sampled farms}

\subsubsection{Benefits of protein crops at the annual scale}

Detailed descriptions of protein-crop management systems were obtained from 64 of the 69 farmers surveyed face to face (the rest of the article concerns these 64 farmers, unless otherwise stated), allowing us to assess performances of these protein-crop management systems. 
For all crops and cropping strategies combined, mean $( \pm$ standard deviation) yield did not differ significantly between conventional and organic systems $(3.5 \pm 0.9$ vs. $3.1 \pm$ $0.6 \mathrm{t} \mathrm{ha}^{-1}$, respectively; Welch's $t$ test, $p=0.07$; Fig. 3 ); this is consistent with the meta-analysis of Seufert et al. (2012), who reported an organic-to-conventional yield ratio of 0.9 for legumes (vs. 0.7 for non-legumes). In addition, variable costs did not differ significantly between conventional and organic systems $\left(294 \pm 126\right.$ vs. $289 \pm 84 € \mathrm{ha}^{-1}$, respectively; Wilcoxon-Mann-Whitney test, $p=0.63$ ). This lack of difference was due to the much higher seed cost for organic systems than for conventional systems $\left(289 \pm 84\right.$ vs. $179 \pm 66 € \mathrm{ha}^{-1}$, respectively; Wilcoxon-Mann-Whitney test, $p<0.001)$. Finally, due to the higher price of organic products (1.5 times as high as that of conventional products), gross profit was significantly higher for organic systems than conventional systems (772 \pm 203 vs. $394 \pm 179 € \mathrm{ha}^{-1}$, respectively; Student's $t$ test, $p<0.001)$. It was difficult to obtain prices for organic seeds and crop grain, but local references (see, for example, GAB/FRAB 2015) indicated that we likely

(a) dry grain yield $\left(\mathrm{t} \mathrm{ha}^{-1}\right)$

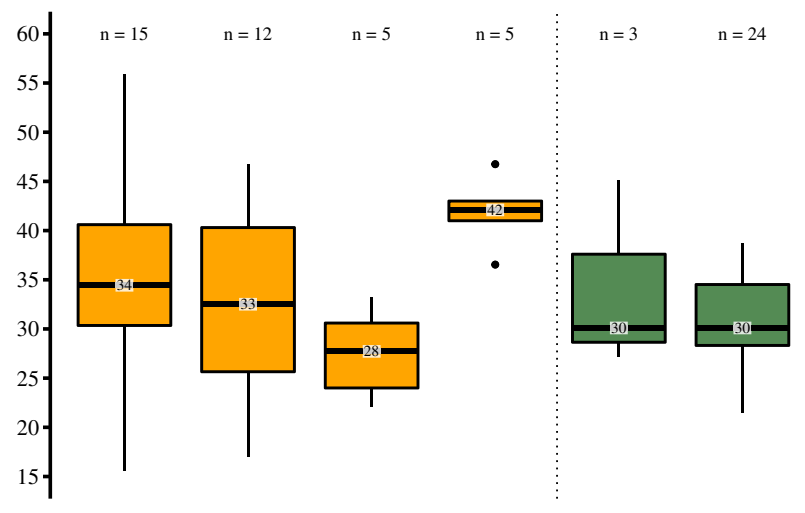

(b) gross profit $\left(€ \mathrm{ha}^{-1}\right)$

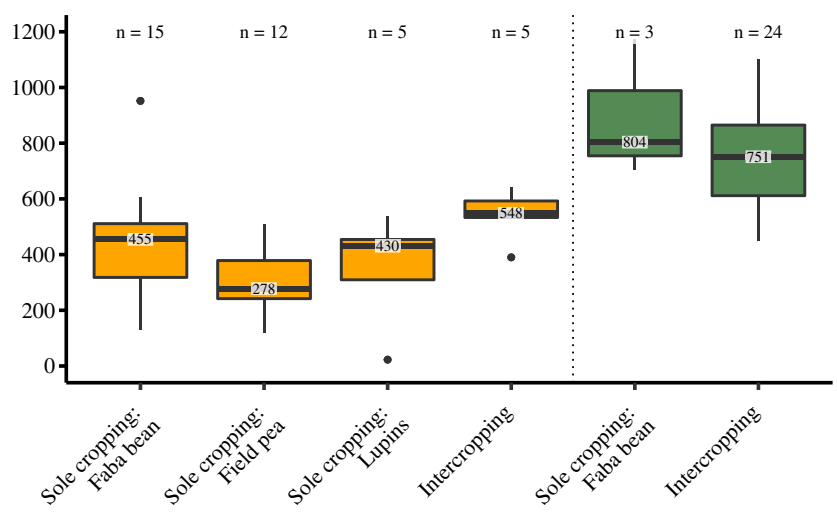

Fig. 3 Performances of 64 crop management systems of protein crops on farms, classified by farming system (conventional farming in orange, organic farming in green), protein crop, and cropping strategy (i.e., intercropping), for (a) dry grain yield and (b) gross profit. Median values are displayed on each boxplot. Each point represents an outlier. Whiskers extend to the most extreme value within 1.5 times the interquartile range overestimated the former and underestimated the latter, thereby possibly underestimating the difference in gross profit between systems.

Mean gross profit of protein crops was approximately one half that of winter wheat in the same region (e.g., Quéré (2015) reported $775 € \mathrm{ha}^{-1}$ as mean gross profit of conventional winter wheat in 2014, in Brittany), which may explain the short-term disadvantage of these crops (especially for conventional systems, since protein crops are often necessary for organic systems due to the exclusion of chemical fertilizers (Zander et al. 2016)). In a recent study of farm-level profitability of protein crops in European cropping systems, Preissel et al. (2015) thoroughly reviewed the difference in gross profit between protein crops and winter wheat; Magrini et al. (2016) confirmed this difference in France. Since protein crops have a higher market price than winter wheat, especially in conventional farming, their lower gross profits are due to differences in yield and variable costs.

Protein crops have lower yields than winter wheat for many reasons, in particular their less advanced crop management practices and plant breeding (Magrini et al. 2016). The negative correlation between yield and protein content (Simmonds 1995) also decreases their yields, due to the carbon cost of nitrogen uptake, nitrogen reduction in the form of amino compounds, translocation of these compounds to seeds, and synthesis of seed proteins (Munier-Jolain and Salon 2005). Consequently, breeding efforts for protein crops remain necessary to increase yield and stabilize it over time, while keeping the protein content of the grain nearly constant (e.g., in the EU project EUCLEG, which focuses on breeding methods and programs for alfalfa, red clover, white clover, faba bean, field pea, and soybean). Meanwhile, since protein crops still have lower yields than winter wheat, farmers who sell protein crops could be paid more for those (i) with higher protein content and/or (ii) favoring GMO-free sectors (as opposed to import-dependent soybean sectors).

Finally, lack of difference in yield between organic and conventional crop management systems should increase the interest of conventional farmers in some organic protein-crop practices: by using the most effective ones in their conventional crop management systems (e.g., the choice of mixed species in intercropping), they could maintain yields while reducing variable costs.

\subsubsection{Benefits of protein crops at the crop-rotation scale}

Most $(65 \%)$ conventional farmers indicated that growing protein crops induced them to decrease nitrogen fertilizer use for the following crop (up to $20 \mathrm{~kg} \mathrm{~N} \mathrm{ha}^{-1}$ for 9 of the 24 farmers who reduced fertilizer use and more than $20 \mathrm{~kg} \mathrm{~N} \mathrm{ha}^{-1}$ for the others), but this left a large minority (35\%) who decided not to do so. Thus, the surveyed farmers do not appear to have sufficiently considered the nitrogen 
pre-crop value of protein crops (i.e., the contribution of protein crops to subsequent crops), given the mean decrease in nitrogen fertilizer use of $23-31 \mathrm{~kg} \mathrm{~N} \mathrm{ha}^{-1}$ reported in 29 experiments and five simulations across Europe, without any loss of yield (Preissel et al. 2017).

Only one organic farmer identified the nitrogen pre-crop effect of protein crops as a way to decrease use of nitrogen fertilizers for the following crop, simply because organic farmers rarely use them. For them, protein crops are one of the primary sources of nitrogen for cropping systems, replacing chemical fertilizers (Stockdale et al. 2001).

Even fewer farmers identified the ability of protein crops to decrease weeds and diseases in the following crop: only eight conventional farmers decreased pesticide use for the following crop, whereas Preissel et al. (2015) reported a decrease in pesticide use of up to $50 € \mathrm{ha}^{-1}$. These results suggest that farmers' agricultural partners (researchers, extension agents, etc.) may need to communicate better about the pre-crop values of protein crops (nitrogen and break-crop effects).

Less than half of the surveyed farmers (42\%) reported that yield of the following crop increased. This increase exceeded $0.5 \mathrm{tha}^{-1}$ for 10 of the 19 conventional farmers and 5 of the 8 organic farmers who reported an increase in yield. Furthermore, 14 of these 19 conventional farmers reported both an increase in yield and a decrease in nitrogen fertilizer use for the crop following protein crops. In similar conventional systems (cereals following broadleaf pre-crops, moderate to high fertilization rates), Preissel et al. (2015) reported no increase in yield (high fertilization rate) or a small increase in yield of $0.1-0.4 \mathrm{tha}^{-1}$ (moderate fertilization rate).

Assuming that one pesticide treatment and $20 \mathrm{~kg} \mathrm{~N} \mathrm{ha}^{-1}$ of nitrogen fertilizer are no longer needed and that yield increases by $0.5 \mathrm{tha}^{-1}$ for a following crop of winter wheat, the pre-crop values identified in our survey represent a potential gain of $118 € \mathrm{ha}^{-1}$ for conventional farmers (based on 2014 data). This is not sufficient to make protein crops as profitable as cereal crops in the short term but is nonetheless a significant contribution to gross profit at the crop-rotation scale, which may explain why conventional farmers continued to grow them. This agrees with the review of Preissel et al. (2015), in which gross profits of crop rotations including protein crops increased in the long term due to the latter's positive effects on soil nitrogen and insect pests.

Finally, surveyed farmers identified several positive longterm effects of protein crops for cropping systems, such as reduction of weed populations (25\%), improvement of soil structure $(25 \%)$, and crop diversification within crop rotations $(22 \%)$. Conventional and organic farmers prioritized different positive long-term effects, the former highlighting crop diversification ( $27 \%$ vs. $15 \%$ of organic farmers) and the latter highlighting nitrogen management and pest and disease management ( $26 \%$ vs. $8 \%$ of conventional farmers).
3.4 Diversity of crop management systems of protein crops

Organic and conventional protein crops had similar productivity despite their diversity of crop management systems (Fig. 4). Studying this diversity allowed us to identify usual and innovative practices.

\subsubsection{Diversity of the type and number of operations}

Crop management systems ranged from simple ones with two operations (sowing and harvest) to more complicated ones with up to 20 operations performed in 17 tractor passes; no single crop management system predominated. Overall, conventional crop management systems had significantly more operations than organic ones $(7.6 \pm 3.6$ vs. $5.1 \pm 1.7$, respectively; Wilcoxon-Mann-Whitney test, $p<0.01)$ due to more pesticide operations after sowing $(1.1 \pm 1.0,0.9 \pm 0.9$, and 0.6 \pm 0.9 fungicide, herbicide, and insecticide operations after sowing, respectively).

\subsubsection{Innovation in weed control}

Weed control has a crucial influence on performances of protein crops: in the online sample, one quarter of the farmers identified weed competition as the most important issue for growing protein crops. In the field, protein crops do not compete with weeds strongly enough to reduce weed abundance (Everwand et al. 2017).

Methods used to control weed populations were common: crop rotation, shallow or deep plowing, mechanical techniques (such as secondary tillage and mowing), and chemical control with herbicides. Many farmers, however, particularly organic ones, performed intercropping, which is a less common method of weed control for French farmers. Use of intercropping to control weeds is consistent with results of several authors (e.g., Gronle et al. 2015; Duchene et al. 2017), who report that intercropping is a valuable method for reducing weed infestation, especially when chemical control is forbidden. CorreHellou et al. (2011) explained that compared to sole cropping, cereal/legume intercropping increases use of available resources (especially, nitrogen and light), which leaves less opportunity for weeds to establish and grow.

The five conventional farmers who performed intercropping used fewer herbicides than those who performed sole cropping: as explained above, this could have been due to the decrease in weed infestation due to intercropping but also because few herbicides are effective for both cereals and legumes. In any case, the use of intercropping in conventional systems could be encouraged by drawing inspiration from organic systems, since organic intercropping does not penalize yield, as mentioned. Obstacles to adopting intercropping can include the cost of 

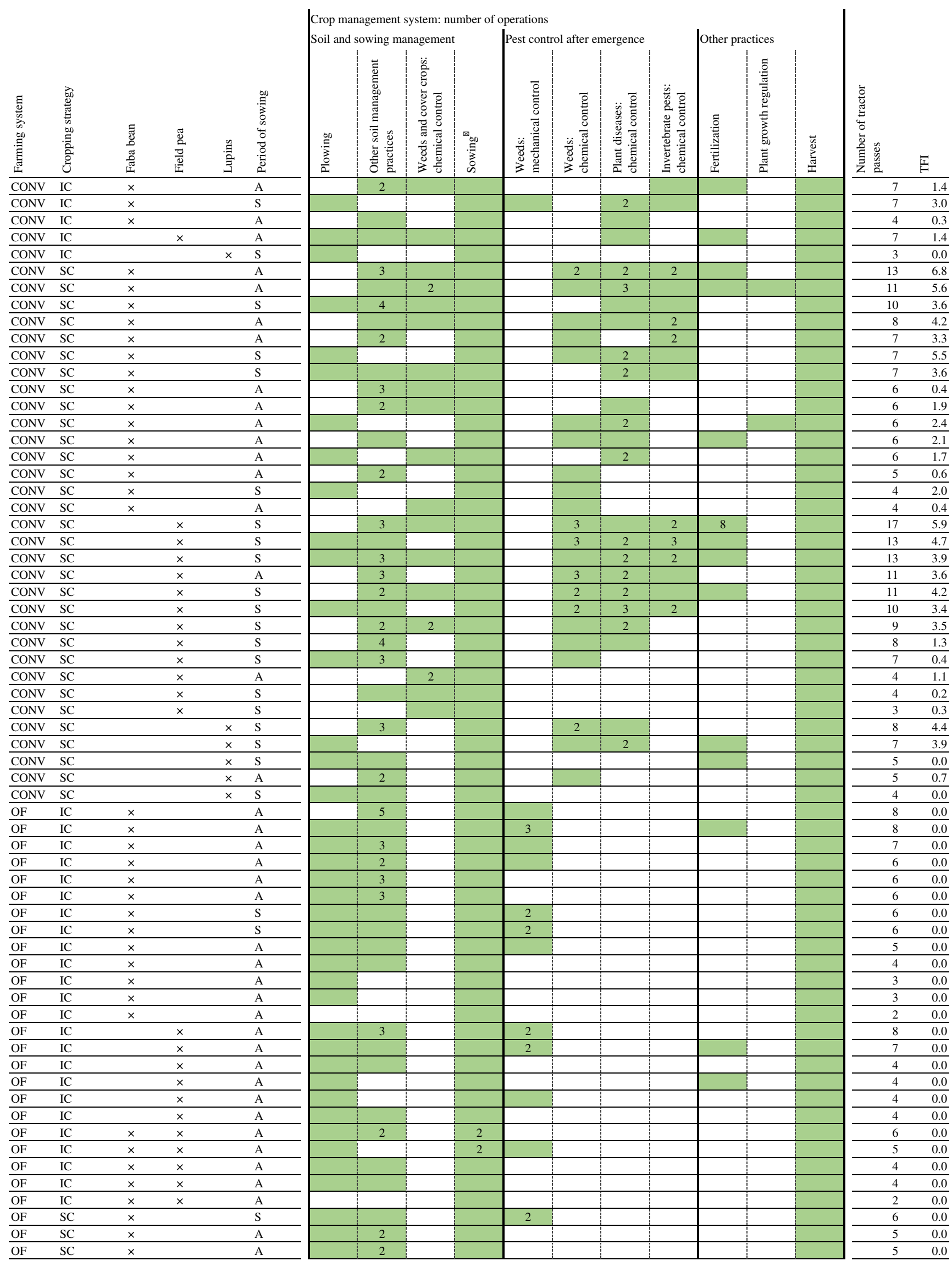
Fig. 4 Description of 64 protein-crop management systems, classified according to farming system (CONV, conventional farming; OF, organic farming), cropping strategy (IC, intercropping; SC, sole cropping), protein crop, number of tractor passes, and period of sowing (S, spring; A, autumn). Green cells indicate that the farmer performed this operation; numbers in green cells indicate the number of times the operation was performed (if $>1$ ). TFI, treatment frequency index. ${ }^{*}$ For 35 of the 64 crop management systems, a combination seed drill was used for sowing (or at least a seed drill and a harrow)

sorting grains if they are not used directly as animal feed, estimated at ca. $30 € \mathrm{t}^{-1}$ (Bedoussac et al. 2015), and the unwillingness of grain-collecting organizations to sort grain.

Another valuable method for weed control is plowing, especially for organic farmers. For Kouwenhoven et al. (2002), plowing is "the best mechanical measure to tackle one of the main problems in organic farming: weed control." It was a widespread practice in our sample for organic farms (24 of 27 ) but much less common for conventional ones (16 of 37 ). Less than half of the organic farmers surveyed used mechanical weed control after emergence of a protein crop (15 of 27), of which most used a combination of plowing and intercropping (11 of 15). If used by conventional farmers, plowing allowed them to decrease the number of herbicide applications before emergence $(0.3 \pm 0.5$ with plowing vs. $0.8 \pm 0.7$ without plowing; Wilcoxon-Mann-Whitney test, $p<0.05$ ) but had no significant effect on treatment frequency index of herbicides (Wilcoxon-Mann-Whitney test, $p=0.27$ ).

\subsubsection{Innovation in pesticide use}

Protein crops not only compete poorly with weeds but also are particularly susceptible to soil-borne pathogens (e.g., Ascochyta spp.) and pests (e.g., Aphis fabae and Acyrthosiphon pisum) (Stoddard 2017). Conventional farmers used chemicals to kill them, but practices differed among farmers: excluding herbicides and plant growth regulators, treatment frequency index varied from 0.0 to 4.5 , being lower for lupins $(0.6 \pm 0.9)$ and intercropping $(1.0 \pm 1.2)$ and higher for faba bean $(1.6 \pm 1.5)$ and field pea $(1.6 \pm 1.4)$. For comparison, median values of treatment frequency index (all pesticides except herbicides) for field pea in 2014 were 1.2 in Brittany and 1.9 in Pays de la Loire (SSP 2016).

Chemical control is not the only way to counteract pathogens that can survive for several years in the soil; one can also rotate crops. Some agronomists recommend growing the same protein crop no more often than every fourth year in a cropping rotation (Stoddard 2017). Surveyed farmers went beyond this recommendation: on average, they grew the same protein crop no more than once every 4.5 years (only 52 cropping rotations were analyzed due to incomplete data).

Cropping rotations of organic farmers contained more legumes than those of conventional farmers: on average, excluding legumes in pasture, legumes were grown once every
3.5 years by organic farmers vs. once every 4 years by conventional farmers. The higher frequency of legumes in organic cropping rotations, which increases the risk of pathogens and pests, is explained by the nitrogen effect of these crops in systems not using chemical nitrogen fertilizers.

\subsubsection{Innovation in soil tillage}

Several surveyed farmers practiced conservation tillage (3 of the 27 organic farmers, 21 of the 37 conventional farmers), but no-tillage cultivation of protein crops was uncommon, performed by only five of the 64 farmers surveyed. For both conventional and organic systems, no tillage resulted in less working time for protein crops than for the systems with tillage $(74 \pm 13$ vs. 180 $\pm 37 \mathrm{~min} \mathrm{ha}^{-1}$, respectively), which is an argument in its favor. However, the other performances were of less interest: for conventional systems, yield and gross profit were particularly low (1.7-3.1 $\mathrm{t} \mathrm{ha}^{-1}$ and $119-455$ $€ \mathrm{ha}^{-1}$, respectively).

A common argument against no tillage is that it makes weed control more complicated, but this was not observed in our sample: treatment frequency index of herbicides for the three systems with no tillage was lower than that for the 34 systems with tillage $(0.6 \pm 0.4$ vs. $1.1 \pm 0.9)$. To further improve performances of protein-crop management systems with no tillage, it could be useful to combine no tillage with intercropping to decrease working time while increasing weed control, thus decreasing effects of weeds on yield.

\subsubsection{Other innovative practices}

Studying the diversity of protein-crop management systems allowed us to identify innovative practices that remained uncommon, for example:

- Sowing faba bean in narrow rows ( $0.14 \mathrm{~m}$ apart) to control weeds. The utility of this practice is questionable, however, since treatment frequency index of herbicides was 1.6 for this system vs. $1.2 \pm 0.7$ for all conventional faba bean systems.

- Broadcast sowing of mixed species (faba bean, field pea, oat, and rye) to reduce working time. Working time for this conventional system was 129 vs. $166 \pm 46 \mathrm{~min} \mathrm{ha}^{-1}$ for all conventional systems. Yield, gross profit, and treatment frequency index were $4.3 \mathrm{tha}^{-1}, 548 € \mathrm{ha}^{-1}$, and 1.4, respectively.

- Broadcast sowing of mixed species (faba bean and winter wheat) with no other operation, except harvesting, to reduce working time. Working time for this organic system was 51 vs. $179 \pm 45 \mathrm{~min} \mathrm{ha}^{-1}$ for all organic systems. Yield and gross profit were $2.4 \mathrm{t} \mathrm{ha}^{-1}$ and $534 € \mathrm{ha}^{-1}$, respectively. 
- Time-shift sowing of two species in intercropping, e.g., broadcast sowing of faba bean and, 4 days later, shallow plowing followed by regular sowing of field pea, triticale, and winter oat. The shallow plowing buries seeds of faba bean at a depth (greater than $0.05 \mathrm{~m}$ ) that protects them from frost, then the three other species are sown at a shallower depth. Working time, yield, and gross profit of this organic system were $159 \mathrm{~min} \mathrm{ha}^{-1}, 2.5 \mathrm{tha}^{-1}$, and 450 $€$ ha $^{-1}$, respectively.

- Complex intercropping (e.g., seven triticale cultivars, two field pea cultivars, and one faba bean cultivar) to improve weed, pathogen, and pest management. Working time, yield, and gross profit of this organic system were $207 \mathrm{~min} \mathrm{ha}^{-1}, 3.0 \mathrm{tha}^{-1}$, and $674 € \mathrm{ha}^{-1}$, respectively.

The scientific literature does not report any robust results for most of these types of innovations, but scientists should examine them to understand why farmers perform them, to assess their performances in-depth, to identify their advantages and disadvantages, and to describe conditions necessary to diffuse them, if desired. For example, scientists could experiment with the complex intercrops described previously to identify advantages of mixing both species and cultivars, since positive effects of these two practices taken separately are well known (e.g., Duchene et al. (2017) for advantages of intercropping species and Borg et al. (2017) for advantages of intercropping wheat cultivars), but the combination of these two practices has not been assessed.

\section{Conclusion}

The online and face-to-face surveys conducted among farmers producing protein crops in western France showed a wide diversity of crop management systems. This diversity concerned (i) variability in the number of operations, (ii) type of weed control, (iii) type of pesticide management, and (iv) isolated innovative practices (such as complex intercropping). Performances of the systems were assessed. The mean profit obtained from protein crops was, as expected, about half that of wheat, confirming that, in the short term, protein crops are less economically attractive than other field crops. Farmers declared that they also grew protein crops because of their agronomic benefits in temporal (crop rotation) and spatial (intercropping) dimensions. Livestock farmers also expressed their satisfaction at replacing imported soybean with farmgrown protein crops, thus increasing their protein self-sufficiency. We therefore insist on the need to consider profit not only at the crop level but also at the crop-rotation level: a short-term vision of protein crop profitability ignores the pre-crop value of protein crops, which decreases nitrogen fertilizer cost for the following crop and increases the latter's yield, thus increasing gross profit. Our survey revealed similar yields of protein crops in organic and conventional systems, even though the former did not use pesticides or chemical fertilizers and grew protein crops at higher frequency in the crop rotation. This can be explained by the more common practice of intercropping and plowing. These results favor growing protein crops with low-input or organic practices, even on conventional farms, if working time is not limited.

Acknowledgments We thank the project partners and students of AGROCAMPUS OUEST who performed the face-to-face surveys. We also thank Michelle L. Corson and Michael S. Corson for proofreading the English. We are grateful to the anonymous reviewers for their constructive remarks.

Funding This work was funded by two French regions, Brittany and Pays de la Loire, in the project SECURIPROT.

\section{Compliance with ethical standards}

Conflict of interest The authors declare that they have no conflict of interest.

Publisher's note Springer Nature remains neutral with regard to jurisdictional claims in published maps and institutional affiliations.

\section{References}

Angus JF, Kirkegaard JA, Hunt JR et al (2015) Break crops and rotations for wheat. Crop Pasture Sci 66:523. https://doi.org/10.1071/ CP14252

Bedoussac L, Journet E-P, Hauggaard-Nielsen H et al (2015) Ecological principles underlying the increase of productivity achieved by cereal-grain legume intercrops in organic farming. A review. Agron Sustain Dev 35:911-935. https://doi.org/10.1007/s13593014-0277-7

Borg J, Kiær LP, Lecarpentier C et al (2017) Unfolding the potential of wheat cultivar mixtures: a meta-analysis perspective and identification of knowledge gaps. Field Crops Res. https://doi.org/10.1016/j. fcr.2017.09.006

Bues A, Preißel S, Reckling M et al (2013) The environmental role of protein crops in the new common agricultural policy. European Parliament, Strasbourg

Cernay C, Ben-Ari T, Pelzer E et al (2015) Estimating variability in grain legume yields across Europe and the Americas. Sci Rep 5:11171

Chambre régionale d'agriculture des Pays de la Loire (ed) (2017) L'agriculture biologique en Pays de la Loire. Résultats de recherche

Core Team R (2016) R: a language and environment for statistical computing. R Foundation for Statistical Computing, Vienna

Corre-Hellou G, Dibet A, Hauggaard-Nielsen H et al (2011) The competitive ability of pea-barley intercrops against weeds and the interactions with crop productivity and soil $\mathrm{N}$ availability. Field Crop Res 122:264-272. https://doi.org/10.1016/j.fcr.2011.04.004

Craheix D (2015) CRITER. http://wiki.inra.fr/wiki/deximasc/package+ MASC/CRITER. Accessed 26 Aug 2016

Duchene O, Vian J-F, Celette F (2017) Intercropping with legume for agroecological cropping systems: complementarity and facilitation processes and the importance of soil microorganisms. A review. Agric Ecosyst Environ 240:148-161. https://doi.org/10.1016/j. agee.2017.02.019 
Eurostat (2015) Agriculture statistics at regional level. http://ec.europa. $\mathrm{eu} /$ eurostat/statistics-explained/index.php/Agriculture statistics at regional_level. Accessed 26 Aug 2016

Everwand G, Cass S, Dauber J et al (2017) Legume crops and biodiversity. In: Murphy-Bokern D, Stoddard FL, Watson CA (eds) Legumes in cropping systems. CABI, pp 70-87

FAO (1961-2011) FAOSTAT Database. In: FAOSTAT. http://www.fao. org/faostat/en/. Accessed 22 May 2018

FranceAgriMer (2016) Données économiques, agricoles et alimentaires. http://visionet.franceagrimer.fr. Accessed 10 May 2016

GAB/FRAB (2015) Grandes cultures biologiques en Bretagne. In: Les fiches techniques du réseau GAB/FRAB. Synthèse Filières. http:// www.agrobio-bretagne.org/wp-content/uploads/2015/04/FICHE_ CEREALES.pdf. Accessed 29 Mar 2017

Gronle A, Lux G, Böhm H et al (2015) Effect of ploughing depth and mechanical soil loading on soil physical properties, weed infestation, yield performance and grain quality in sole and intercrops of pea and oat in organic farming. Soil Tillage Res 148:59-73. https:// doi.org/10.1016/j.still.2014.12.004

Häusling M (2011) The EU protein deficit: what solution for a longstanding problem? (2010/2111(INI)). European Parliament, Strasbourg

IBB (ed) (2015) Le point bio sur... la filière "Grandes Cultures Bio" en Bretagne

Kouwenhoven JK, Perdok UD, Boer J, Oomen GJM (2002) Soil management by shallow mouldboard ploughing in the Netherlands. Soil Tillage Res 65:125-139. https://doi.org/10.1016/S0167-1987(01) 00271-9

Lucas MM, Stoddard FL, Annicchiarico P et al (2015) The future of lupin as a protein crop in Europe. Front Plant Sci 6:705. https://doi.org/10. 3389/fpls.2015.00705

Magrini M-B, Anton M, Cholez C et al (2016) Why are grain-legumes rarely present in cropping systems despite their environmental and nutritional benefits? Analyzing lock-in in the French agrifood system. Ecol Econ 126:152-162. https://doi.org/10.1016/j.ecolecon. 2016.03.024

Mahé L-P, Laroche-Dupraz C (2000) La politique agricole dans les négociations internationales. Écon Rural 255:135-153. https://doi. org/10.3406/ecoru.2000.5166

Meynard J-M, Charrier F, Fares M et al (2018) Socio-technical lock-in hinders crop diversification in France. Agron Sustain Dev 38:54. https://doi.org/10.1007/s13593-018-0535-1

Munier-Jolain NG, Salon C (2005) Are the carbon costs of seed production related to the quantitative and qualitative performance? An appraisal for legumes and other crops. Plant Cell Environ 28:13881395. https://doi.org/10.1111/j.1365-3040.2005.01371.x

Murphy-Bokern D, Watson CA, Stoddard F, et al (2014) Outlook for knowledge and technology for legume-supported cropping systems. Legume Futures Report 5.3

Peyronnet C, Lacampagne J-P, Le Cadre P, Pressenda F (2014) Les sources de protéines dans l'alimentation du bétail en France : la place des oléoprotéagineux. OCL 21:D402. https://doi.org/10. $1051 / \mathrm{ocl} / 2014012$

Pôle Agronomique Ouest (2016) PROGRAILIVE: context and objectives. http://www.pole-agro-ouest.eu/uk/sos-protein/prograilive/. Accessed 10 May 2016

Preissel S, Reckling M, Schlaefke N, Zander P (2015) Magnitude and farm-economic value of grain legume pre-crop benefits in Europe: a review. Field Crop Res 175:64-79. https://doi.org/10.1016/j.fcr. 2015.01.012

Preissel S, Reckling M, Bachinger J, Zander P (2017) Introducing legumes into European cropping systems: farm-level economic effects. In: Murphy-Bokern D, Stoddard FL, Watson CA (eds) Legumes in cropping systems. CABI, pp 209-225

Quéré L (2015) Analyse des marges cultures 2014 en Bretagne. Terra $30-31$

Reckling M, Bergkvist G, Watson CA et al (2016) Trade-offs between economic and environmental impacts of introducing legumes into cropping systems. Front Plant Sci 7. https://doi.org/10.3389/fpls. 2016.00669

Ridier A, Chaib K, Roussy C (2016) A dynamic stochastic programming model of crop rotation choice to test the adoption of long rotation under price and production risks. Eur J Oper Res 252:270-279. https://doi.org/10.1016/j.ejor.2015.12.025

Seufert V, Ramankutty N, Foley JA (2012) Comparing the yields of organic and conventional agriculture. Nature 485:229. https://doi. org/10.1038/nature11069

Simmonds NW (1995) The relation between yield and protein in cereal grain. J Sci Food Agric 67:309-315. https://doi.org/10.1002/jsfa. 2740670306

SSP (2016) Agreste, la statistique agricole. In: Agreste, la statistique agricole. http://agreste.agriculture.gouv.fr/english-version/homepage/. Accessed 10 May 2016

Stockdale EA, Lampkin NH, Hovi M et al (2001) Agronomic and environmental implications of organic farming systems. Adv Agron 70: 261-327. https://doi.org/10.1016/S0065-2113(01)70007-7

Stoddard FL (2017) Grain legumes: an overview. In: Murphy-Bokern D, Stoddard FL, Watson CA (eds) Legumes in cropping systems. CABI, pp 70-87

Voisin A-S, Gueguen J, Huyghe C et al (2014) Legumes for feed, food, biomaterials and bioenergy in Europe: a review. Agron Sustain Dev 34:361-380. https://doi.org/10.1007/s13593-013-0189-y

von Richthofen J-SV, Pahl H, Bouttet D et al (2006) What do European farmers think about grain legumes? Grain Legumes 45:14-15

Watson CA, Reckling M, Preissel S et al (2017) Grain legume production and use in European agricultural systems. Adv Agron 144:235-303. https://doi.org/10.1016/bs.agron.2017.03.003

Zander P, Amjath-Babu TS, Preissel S et al (2016) Grain legume decline and potential recovery in European agriculture: a review. Agron Sustain Dev 36:1-20. https://doi.org/10.1007/s13593-016-0365-y

Zimmer S, Liebe U, Didier J-P, Heß J (2016) Luxembourgish farmers' lack of information about grain legume cultivation. Agron Sustain Dev 36:2. https://doi.org/10.1007/s13593-015-0339-5 